\section{The Potential of a Critical Cartography Based on Immanent Critique}

GI_Forum 2020, Issue 2

Page: 79 - 95

Full Paper

Corresponding Author: michael.lehner@uni-due.de DOI: 10.1553/giscience2020_02_s79

\author{
Michael Lehner'and Inga Gryl' \\ 'University of Duisburg-Essen, Germany
}

\begin{abstract}
This paper argues for the potential of a critical cartography based on immanent critique or more precisely, a practice for educational contexts that fosters reflexive map-reading based on immanent critique. It starts with a discussion of contrasting approaches based on discourse analysis and immanent critique. This provides first insights into how one can overcome problems based on discourse analytical framings by using an approach rooted in immanent critique. At the same time, it shows how immanent critique can nevertheless benefit from discourse analysis. This interplay fosters a particular practice of reflexive mapreading that offers the potential to foster 'maturity' ('Mündigkeit') (Adorno \& Becker, 1971) and the 'political subject' (Mitchell, 2018; Mitchell \& Elwood, 2013) in educational contexts.
\end{abstract}

\title{
Keywords:
}

immanent critique, deconstruction, maturity, education, spatial citizenship, critical cartography, discourse analysis

\section{Introduction}

Critical Cartography already offers more than three decades of tradition. Glasze (2009), for example, summarizes the developments in cartography using 3 paradigms: (1) the map as an image of reality; (2) the map as an effect of social structure, and (3) the map as a producer of social reality. To illustrate the first paradigm, the Diercke-Dictionary for Geography defined 'cartography', at least until the 2005 edition', as a 'true-to-scale image of the earth's surface' (Leser \& Broll, 2005; quoted after Glasze, 2009; own translation). In opposition to this paradigm, the development of critical cartography started in the 1980s and early 1990s (Schuurman, 2000). This initial phase is closely linked to the theoretical writings of John Brian Harley (1989; 1988; 1988) (see Crampton \& Krygier, 2010).

In his canonical paper 'Deconstructing the Map', Harley (1989) refers to Derrida and Foucault. Using a Derridean perspective, he examines the 'textuality of maps and, in particular, their rhetorical dimension' (p. 2). With this emphasis on their rhetorical dimension, Harley tries to

\footnotetext{
${ }^{1}$ In its current edition (2017), the Diercke-Dictionary defines 'cartography' as 'a field of art, science and technology for the production and usage of maps [...]' (Leser \& Broll, 2017; own translation).
} 
overcome the idea of the map as an image of reality and argues for 'an epistemological shift in the way we interpret the nature of cartography' (p. 1). He breaks with the 'realistic paradigm' (paradigm 1) (Glasze, 2009, p. 183), which treats cartography as 'an "objective" form of knowledge creation' (Harley, 1989, p. 1). Based on a Foucauldian perspective, Harley proposes 'to draw a distinction between external [paradigm 2] and internal [paradigm 3] power in cartography' (p. 12). He describes 'external power' as 'power exerted on cartography. Behind most cartographers there is a patron; in innumerable instances the makers of cartographic texts were responding to external needs' (p. 12). Glasze (2009) interprets this idea as the root of paradigm (2), which treats the map as an effect of social structure. Paradigm (3), which treats the map as a producer of social reality, would be rooted in Harley's concept of internal power (see Glasze 2009, 184), which basically claims that 'power is also exercised with cartography' (Harley 1989, 12); see also Wood's 'The power of maps' (1993).

Gryl and Kanwischer (2011) identified a gap concerning reflexive map work in their review of geography education literature. The Spatial Citizenship approach addresses this gap. The approach is well rooted in critical cartography, with a focus on spatial-societal participation through the reflexive use of geomedia, such as (digital) maps (Gryl \& Jekel, 2012; Jekel et al., 2015). In this paper, we will follow this tradition and try to further examine the reflexive use of geomedia for educational contexts with the aim of fostering 'maturity' ('Mündigkeit') (Adorno \& Becker, 1971), and with that the 'political subject' (Mitchell, 2018; Mitchell \& Elwood, 2013).

In particular, we will focus on a specific mode of reflectivity, namely critique. We will start this paper with a discussion of different modes of critique and will try to show that a Foucauldian approach to critical cartography also (along with all its strengths) has significant limitations. In contrast to Foucauldian approaches, as utilized by Harley (1989), we will discuss Jaeggi's approach of immanent critique (Jaeggi, 2013). We will argue that this mode offers the potential to overcome the limitations of critical cartography based on discourse analysis, but at the same time it can still benefit from some aspects of Foucault's approaches. In the last section, we will present some initial insights into a potential interplay of discourse analysis and immanent critique for critical cartography, and in particular a practice of reflexive map-reading that offers the potential to foster 'maturity' ('Mündigkeit') (Adorno \& Becker, 1971) and the 'political subject' (Mitchell, 2018; Mitchell \& Elwood, 2013) in educational contexts.

\section{Four problems of critical cartography based on discourse analysis}

\section{1 'The map' as fetish}

The first problem we would like to illustrate is closely linked to Harley's (1989) approach of 'Deconstructing the Map'. As this particular paper has already been discussed widely, ${ }^{2}$ we will summarize just briefly some potentials and limitations of Harley's approach. As discussed in Lehner et al. (2018), Harley's perspective supports a better 'understanding of the power of cartographic representation' (Harley, 1989, p. 15). However, due to its eclectic framing of

${ }^{2}$ See for example the 2015 special issue of Cartographica celebrating the 25th anniversary of Harley's 'Deconstructing the Map'. 
postmodern theories with hermeneutics, Harley limits the critical potential of his approach to the interpretation of maps. This helps to fruitfully criticize maps with a focus on the power of cartographic representation, ${ }^{3}$ but shows its limitation in the critique of power relations as such. This leads to the following potentials and limitations:

Table 1: Potentials and limitations of Harley's approach (Lehner et al., 2018)

\begin{tabular}{l|l} 
potentials & limitations \\
\hline $\begin{array}{l}\text { to question the influence of e.g. } \\
\text { institutions on the 'map'... }\end{array}$ & but not the institutions as such; \\
\hline $\begin{array}{l}\text { to understand 'the map' as an } \\
\text { instrument of power... }\end{array}$ & $\begin{array}{l}\text { but power relations are treated as a } \\
\text { means to an end, ... }\end{array}$ \\
$\begin{array}{l}\text { to question and uncover implied } \\
\text { ideologies of the map... }\end{array}$ & but not power-relations as such. \\
\hline
\end{tabular}

The point is, as Belina (2013) argues against Harley, that 'maps - like all forms of knowledge - do not have power-effects just by existing, but only if they effect social practices' (p. 152; own translation). Thus, the first problem we would like to illustrate is that a critical cartography that is closely linked to Harley's approach is in danger of exhausting itself in a critique of maps, thus losing the potential to critique social relations (problem \# 1).

\subsection{Unintended discursive effects of critical cartography based on discourse analysis}

Crampton and Krygier (2010) tackle the question 'What is critique?' in their introduction to critical cartography. They frame critique as 'a politics of knowledge. First, it examines the grounds of our decision-making knowledges; second it examines the relationship between power and knowledge from a historical perspective; and third it resists, challenges and sometimes overthrows our categories of thought' (Crampton \& Krygier, 2010, p. 14). This understanding of critique is clearly inspired by a Foucauldian perspective ('it examines the relationship between power and knowledge'; see Foucault, 2017a).

Foucauldian discourse analysis plays a prominent role in critical cartography not only for Crampton and Krygier (2010). In Glasze's (2009) introduction to critical cartography as well Harley's canonical paper, Foucault's (early) discourse theory - in combination with his concept of power - provides the foundation for a critique of maps. So, one can clearly claim that discourse analysis plays a prominent role in critical cartography, which can be traced back to Harley's 'Deconstructing the Map'.

If we take a closer look at Foucauldian concepts, they are without doubt powerful instruments to question the seemingly normal or natural. Pinder (2003) (based on Harley), for example, discusses four aspects of reflexive map usage inspired by discourse analysis (hierarchization:

\footnotetext{
${ }^{3}$ For example, to criticize the influence of institutions such as 'monarchs, ministers, state institutions, [or] the Church' (Harley, 1989, p. 12) on the map (external power), and beyond that the discursive effect of a map that has been thus influenced (internal power).
} 
What is displayed more prominently?; concealment: What is missing?; geometry: What kind of projection is used, what is centred?; symbols: How is colour used?). Clearly, this is very useful to overcome the concept of the map as 'an "objective" form of knowledge creation' (Harley 1989, 1): the approach offers adequate tools to critically examine maps, including the maps' internal power. Therefore, Harley's mode of critical cartography helps to criticize hierarchizations in maps such as 'the place of the king is more important than the place of a lesser baron, [...] a castle is more important than a peasant's house' (Harley 1989, 7). But, is it enough to criticize hierarchizations and marginalization in maps, and with that break the potential discursive and normalization effects of the map ('power exercised with cartography' - paradigm 3)?

Even if we delve deeper, using Foucault's concept of the 'episteme' (Foucault, 2017b) as an artefact of hierarchized space, as a mirror to interpret this hierarchization in the map as a trace of deeper social structures (the hierarchical place of the king in the map would represent his hierarchical place within the social order - paradigm 2), the potential critique of the hierarchization in the social order would still be at the level of a single negation of a hegemonic position. Žižek, for example, argues that such modes of critique are not sufficient. He insists that we need a critique 'which opens up a new space outside the hegemonic position and its negation' (Žižek, 2012, p. 1007).

It seems that $\check{Z}$ ižek has a point here: Boltanski and Chiapello (2006) examined different modes of critique of capitalism in a historical-empirical way. One outcome of this exploration is that critique is in danger of fostering what Gramsci calls a 'passive revolution' (L. Becker et al., 2017), a transformation within an existing regime, like the transformation from a Fordian mode of production to a neoliberal one. Candeias (2008) follows this argumentation and shows how state criticism of the movements of 1968 was deferred on the terrain of neoliberalism to foster privatizations and a reduction of state control against the movement's intention.

Žižek's point that a single negation of a hegemonic position (as such, and not only within the map) is not enough, finds its echo in these historical developments. The point we are trying to develop here is that the discursive effects of critical interventions of a reflexive map usage based on discourse analysis cannot be assessed in advance. Therefore, it is constantly at risk of being deferred on the terrain of the criticized hegemonic position against its own intention, as happened with the state criticism by the movements of 1968 (problem \# 2):

Demirović (2008) argues that it is not enough to criticize the circumstances in which people are enslaved and exploited. At the same time, we need to criticize the scales of critique, and to analyse their practical functionalities and the consequences of critique. Demirović basically insists on meta-critical reflections (see 2008, p. 29).

While the Spatial Citizenship approach already implies these thoughts about critique in its theoretical framework with its focus on a combination of reflection and reflexivity ${ }^{4}$ (Gryl \& Jekel, 2012; Jekel et al., 2015), in this paper we are looking for a practice which specifies and applies these thoughts on critique within the Spatial Citizenship approach.

\footnotetext{
${ }^{4}$ In the context of critical reflexive map usage, reflection implies the performed critique of the map as well as of the social relations to which the map refers; reflexivity implies meta-critical reflections on one's own thinking, acting with the map, and social relations. (See Demirović (2008).)
} 


\subsection{The problem of normativity and legitimation}

Foucauldian discourse analysis has its anchor point in the thesis of the immanence of power, power which could come from anywhere (Foucault, 2017a, p. 114). With this, Foucault 'deidealized scientific thought by revealing its intrinsic discursive materiality' (Vighi \& Feldner, 2007 , p. 151). So, every claim or statement communicated via maps is suspicious of its 'politics of knowledge' (Crampton \& Krygier, 2010, p. 14). While this perspective has great potential for a 'thorough denaturalization and dereification of entrenched notions of the social' (Vighi \& Feldner, 2007, p. 151), it fails to legitimate critique. Foucault describes critique as 'the movement by which the subject gives himself the right to question truth on its effects of power and question power on its discourse of truth' (Foucault, 2007, p. 47). Linked to this perspective are questions such as: How can we question truth on its effects of power? Is it possible to describe these effects of power objectively? What is the normative viewpoint of the discourse researcher? Do we need a normative dimension to claim that identified power effects are negative? Is there a normative position that is superior, which legitimates this potential normative position?

Foucault tries to avoid normative argumentation and thereby to avoid all problems of the legitimation of normative positions. He basically limits himself to revealing power structures and power effects - without the adaptation of any explicit normative position. For example, Foucault historizes concepts, such as 'madness', which at first sight seem to have no history (Foucault, 1988). He impressively shows that such concepts do indeed have a genealogy and have changed over time, instead of being naturally defined. From this illustration of the history of a criticized concept, it is only one further step to link madness and its institutions to power structures and power effects. The problem is that one could simply turn this argument against itself: What if we turn this strategy of revealing power structures and power effects against discourse researchers, based on a second-order discourse analysis? What power effects come from discourse analysis? What power effects come from the seemingly objective description of power effects?

The point we are trying to develop is that Foucault's avoidance of normative critique leads into an 'infinite regress' (Albert, 2010), a never-ending cycle of legitimation and de-legitimation (see Herzog, 2013; Vighi \& Feldner, 2007). While Harley (1989) already implicitly used the normative position of equality in his critique of hierarchization, more recent approaches of critical discourse analysis (CDA) try to avoid the 'infinite regress' by adopting a normative viewpoint as well. For example, van Dijk (2009) links discourse analyses to particular norms and values such as human rights, using concepts such as 'discursive injustice'. However, with this normative framing we simply come back to the problems of the legitimation of normative positions. ${ }^{5}$ The question of the legitimation of critique in a critical cartography that is based on discourse analysis remains unanswered - it ends either in the treadmill, or in problems linked to the legitimation of normative positions (problem \# 3). ${ }^{6}$

\footnotetext{
${ }^{5}$ We will discuss the problem of the legitimation of normative positions in more depth in section 3 .

${ }^{6}$ This is a serious problem. The thinktank of the so-called new right, the Institut für Staatspolitik, has used this argument since at least 2004 and tries to discredit critique as such (Institut für Staatspolitik, 2004).
} 


\subsection{The silence of discourse analysis: questioning the obstacle}

The fourth - and for us the most important - problem with cartography based on discourse analysis concerns its transformative potential.

Discourse analysis offers great potential in historicizing 'concepts which were thought to have no history' (Vighi \& Feldner, 2007, p. 151), which seemed to be natural or objective, as we discussed in relation to the concept of 'madness' (Foucault, 1988). Discourse analysis describes its object of investigation in a new and provocative way, which leads to a change of perspective, to seeing the object or topic in a different light (e.g. the 'modern' system of sanctions (Foucault, 1995)). That said, discourse analysis obviously has subversive potential (Butler, 2016; Saar, 2007, 2016).

As already stated, along with Harley (1989) we can criticize the hierarchization of space (in maps) based on discourse analysis. While we absolutely agree that this is an important task, we think it is also important to show that this mode of critique exhausts itself in identifying the hierarchization. In contrast to immanent critique, it does not ask what the obstacle is that prevents change. The identification of hierarchization is one thing, but what prevents the change or the abolishment of hierarchization? Historicizing concepts (e.g. madness) is an important task because it offers a hint of the possibility of change. But discourse analysis remains silent with regard to the obstacle; it neither offers an (explicit) reason why what is criticized should be changed, nor does it identify what prevents the change (problem \# 4). This is exactly where immanent critique shows its strength.

\section{Immanent critique}

In contrast to Crampton's and Krygier's (2010) understanding of critique, with its Foucauldian framing, Jaeggi (2013) differentiates between external critique, internal critique and immanent critique.

External critique uses criteria 'from the outside' to assess what is being criticized. A critique in this sense is like a normative theory in the form of a judgement. For example, one could use human rights as a scale for measuring an existing position. In this sense, external critique has a transformative potential: one can use a normative theory and contrast what exists with it, even if this perspective from the 'outside' is not yet legitimated in what exists. On the other hand, though, it is difficult to legitimate the position from which the critique is expressed ('outside'), even if we refer to human rights: interventions based on human rights are in danger of becoming so-called 'civilizing missions' with an imperialistic taint (Spivak, 2007; Varela \& Dhawan, 2015). The problem with external critique is that the position from which the critique is expressed remains ambiguous (see Jaeggi, 2013, pp. 261ff) (as we discussed with problem \# 3).

This problem can be solved by the use of internal critique. Internal critique seeks its scale 'within the criticized itself. For example, one can blame a staff manager who publicly promotes gender equality if he or she invites applications from male candidates only. Internal critique refers to standards that already exist and criticizes their violation. Internal critique is very 
convincing - who would like to be accused of violating their own ideals? The problem with internal critique is that it implies a conservative character and lacks transformative potential, because it exhausts itself in the compliance and recovery of the existing (see Jaeggi, 2013, pp. 263-277).

Immanent critique combines the strengths of external and internal critique. It has transformative potential and develops its scales or criteria 'within what is criticized itself. Immanent critique does not approach what exists with a preconceived ideal. Rather, it tries to reveal immanent contradictions within what exists, by emphasizing the ideals of what exists. Romero $(2014$, p. 7) claims that immanent critique fosters a self-criticism of existing social relations. One prominent example of immanent critique comes from Marx: the double sense of freedom in bourgeois-liberal societies. Marx argues that the concept of freedom plays an important role in the self-perception of bourgeois-liberal societies. In fact, in contrast to e.g. feudal societies, the choice of labour is free, but at the same time the worker is free from means of production, and as soon as he or she gets hungry, is forced to sell his or her labour power under a capitalist mode of production. Marx argues that there is bondage in seemingly free liberal societies - or in his own words: the 'worker must be free in the double sense that as a free individual he can dispose of his labor-power as his own commodity, and that, on the other hand, he has no other commodity for sale, i.e. he is rid of them, he is free of all the objects needed for the realization of his labor-power' (Marx, 1981, p. 272).

The scale for the critique of the bourgeois-liberal society is found in this Marxian example from 'within the criticized itself' - the ideal that bourgeois-liberal societies are 'free' societies. This reference to standards or ideals that already exist legitimates the position of the critique, as we discussed with internal critique. This solves problem \# 3. In contrast to internal critique though, Marx's critique does not exhaust itself in the compliance and recovery of what exists. It has transformative potential because it reveals immanent contradictions within bourgeoisliberal societies: the worker, who is free to choose, is at the same time free from means of production and is therefore forced to sell his or her labour power under the existing conditions. This contradiction cannot be solved under existing conditions, because it is an immanent part of existing relations. At the same time, this mode of critique reveals the obstacle that prevents the change, which solves problem \# 4 .

This helps to solve problem \# 2 as well - the problem of unintended discursive effects - as discussed based on the historical examples of critique of capitalism, which were deferred on the terrain of the criticized hegemonic position. As mentioned, Žižek claims in this regard that we need a critique 'which opens up a new space outside the hegemonic position and its negation' (Žižek, 2012, p. 1007). This is exactly what immanent contradictions offer: 'it surpasses the corrective critique by revealing the systemic difficulties of fulfilling the demands' (Herzog 2026, p. 284). So, the new space outside the hegemonic position and its negation are opened up by revealing specific systemic difficulties of fulfilling the demands, as we see in the Marxian critique of bourgeois-liberal societies: workers are described as free in the double sense. This critique does not simply negate the claim of freedom within bourgeois-liberal societies; it paradoxically reveals a relation between the claim of freedom and its criticized opposite - bondage: as soon one gets hungry, one is forced to sell one's labour power under a capitalistic mode of production, because the worker is free from means of production. 
Immanent critique does not describe a new space outside the hegemonic position and its negation as an essentialist utopia, but it opens a way to them. This does not completely eliminate the danger for the critique of being deferred on the terrain of the hegemonic position that is being criticized, but its more precise description of the obstacle should help to avoid unintended discursive effects.

Stahl (2013, own translation) distinguishes between two different types of immanent critique: 'hermeneutic' and 'practice-based' (p. 533). He argues that the 'practice-based model of immanent critique differs from a hermeneutic model insofar as it locates the norms, which the critique employs, within the rules of common social practices, rather than within shared understandings' (ibid.). So, the hermeneutic approach takes its critical norms from a reinterpretation of explicitly acknowledged standards. Stahl criticizes that the hermeneutic approach exhausts itself in 'a new interpretation of the ideals of bourgeois liberty, pointing out some hitherto unacknowledged aspects of their meaning' (ibid., p. 535). He argues that a critique of the cultural meanings of accepted standards in a given community is not enough, and he promotes a focus on the communities' practices and institutions: 'Practice-based immanent criticism thus presupposes that the structures and modes of interaction in a social community contain - beyond the explicit understanding of their participants - immanent normative potentialities upon which a critic can draw' (ibid.). A practice-based form of immanent critique 'demands the change of both the actual practice and the explicitly accepted norms of the community' (ibid.).

This discussion of 'hermeneutic' and 'practice-based' immanent critique brings us back to problem \# 1: how critical cartography that is closely linked to Harley's (1989) approach of 'Deconstructing the Map' exhausts itself in a critique or reinterpretation of the map and its normative implications. This approach does not aim to change social practices - at least not in a direct way. Although practices can be seen as 'discursively created, shaped and interpreted by social actors, the primary focus of the analysis required for this type of critique must be practices and not more or less conscious language use' (Herzog, 2016, p. 283).

Belina (2009, 2010, 2011), for example, focuses on practices during the production of crimemaps ('external power'), as well as on the practices fostered by these maps ('internal power'). One central characteristic of the production of maps, Belina argues, is 'abstraction' (Belina, 2010, p. 9). The data for crime-maps usually comes from crime statistics, but what is counted as a crime? Belina describes several requirements ('filters', p. 11) that need to be met for something to count as a crime - questions of the law, of course, but also subjective perception, and complaining to the police. For example, drug-crimes are against the law but are rarely reported to the police by citizens; they usually get into crime statistics based on police control. Belina mentions drug-maps as an example of such abstractions. Such maps suggest that close to the German-Netherlands border, drug-crimes would be higher. However, based on the examination of practices that lead to the production of such maps, it is more likely that these maps are the result of greater police controls at the border, and not necessarily higher numbers of drug-crimes or consumption of illegal drugs. This practice of abstraction may lead to the production of an ideology that could influence the intensity of police control fostered by these maps, leading to a vicious circle or 'self-fulfilling prophecy' (p. 15). 
While this example of a practice-based analysis of crime-maps shows the potential of going beyond a critique of the map as such (problem \# 1), immanent critique is in addition a critique based on norms that are already accepted - at least within a hegemonic position. These norms are not always obvious and are often only implicitly present in practices (see Herzog, 2016, p. 284). They need to be uncovered somehow, and here discourse analysis can help a critical cartography based on immanent critique. While immanent critique does not offer tools for determining the implicit norms, 'for discourse analysts, revealing the implicit structures of discourses is everyday work and should not be overly complicated' (ibid.).

Table 1: Summary of the central arguments

\begin{tabular}{|c|c|c|}
\hline & $\begin{array}{l}\text { Problems of critical cartography } \\
\text { based on discourse analysis }\end{array}$ & $\begin{array}{l}\text { How immanent critique (IC) overcomes this } \\
\text { problem }\end{array}$ \\
\hline$\# 1$ & 'The map' as fetish & $\begin{array}{l}\text { IC tries to question social practices and } \\
\text { not only implied ideologies of the map }\end{array}$ \\
\hline$\# 2$ & $\begin{array}{l}\text { Unintended discursive effects of } \\
\text { critical cartography based on } \\
\text { discourse analysis }\end{array}$ & $\begin{array}{l}\text { IC does not describe a new space outside } \\
\text { the hegemonic position and its negation as } \\
\text { an essentialist utopia, but it opens a way } \\
\text { to them. This does not completely } \\
\text { eliminate the danger for the critique to } \\
\text { be deferred on the terrain of the } \\
\text { criticized hegemonic position, but its } \\
\text { more precise description of the obstacle } \\
\text { should help to avoid unintended discursive } \\
\text { effects }\end{array}$ \\
\hline$\# 3$ & $\begin{array}{l}\text { The problem of normativity and } \\
\text { legitimation }\end{array}$ & $\begin{array}{l}\text { IC finds the scale for the critique } \\
\text { 'within the thing criticized itself' }\end{array}$ \\
\hline$\# 4$ & $\begin{array}{l}\text { The silence of discourse analysis: } \\
\text { Questioning the obstacle }\end{array}$ & $\begin{array}{l}\text { IC tries to reveal the obstacle as } \\
\text { immanent contradiction }\end{array}$ \\
\hline
\end{tabular}

\section{Critical cartography based on immanent critique and discourse analysis}

A practice for critical cartography - or more precisely, a practice for reflexive map-reading that fosters 'maturity' ('Mündigkeit') (Adorno \& Becker, 1971) and with that the 'political subject' (Mitchell, 2018; Mitchell \& Elwood, 2013) in educational contexts - could start with tools derived from discourse analysis. The aim of this first phase is the identification of implied norms derived from textual and non-textual aspects (e.g. practices, institutions) that are linked to the map - as 'discursively created, shaped [...or] interpreted' (Herzog, 2016, p. 283). The second phase would be the phase of immanent critique, which would have its starting point in the result of the first phase: the implied norms derived from textual and non-textual aspects linked to the map. To illustrate the potential of such an interplay of discourse analysis and immanent critique, we provide a short example below (see 4.2), but first we outline steps that we think helpful for such a practice. 


\subsection{Helpful steps for a critical cartography based on immanent critique and discourse analysis}

The analysis during the first phase (based on discourse analysis) needs to focus on textual and non-textual (e.g. practices, institutions) aspects that influence the production of the map, as well as textual and non-textual aspects that are (potentially) influenced by the map produced (as discussed earlier with Harley's concepts of external and internal power and with Belina's critique of crime-maps). Practice could consist of the following steps:

1. first approximation

1.1. general characterization of the map: source and political localization of the source, intended readership, circulation, etc.

1.2. allocation of thematic areas (crime, economy, education, etc.)

2. fine analysis

2.1. What textual and non-textual (e.g. practices, institutions) aspects influence the production of the map (related to Harley's concept of external power: What is the specific practice of e.g. data acquisition? What are the rules that permit the statements of the map?)

2.2. How is this map used? (related to Harley's concept of internal power: What is the discursive effect of the map? What are potential practices fostered by these discursive effects?)

3. summary

3.1. How can the discourse strands which influenced the production of the map, as well as those that are influenced by the resulting map, be described?

3.2. What are their implicit norms? What is the most prominent one?

3.3. Finding a corresponding practice: every norm refers to a practice. What is the practice corresponding to the identified norm?

Now that we have identified the implicit norm, it is time for the second phase: the analysis regarding an immanent contradiction. This could consist of the following steps (see Jaeggi, 2013, pp. 297-298):

4. Examining the relationship between norm and its conflicting practice

a) internal critique only criticizes the difference between an accepted norm and its conflicting practice (e.g. promoting gender equality but inviting only male candidates for job interviews)

b) immanent critique examines a relationship between both, in the sense that the norm is even constitutive for the practice criticized (as illustrated by the Marxian example discussed earlier)

c) immanent critique analyses whether the norm is realized in the practice deficiently (in the Marxian example, the norm (freedom) is realized in the practice deficiently in that it became transformed into a type of bondage)

5. Further discussion of the immanent contradiction that has been revealed: Which questions can be asked on the basis of the immanent contradiction? What are the new insights generated by the immanent contradiction? 


\subsection{Example as Model}

We will now put these abstract steps into a specific context to further clarify them, using a map with the title 'equity in education'.

1. First approximation: The map ${ }^{7}$ shows the findings of a survey conducted by the Programme for International Student Assessment (PISA). In particular, this map shows the influence of social background on what PISA describes as performance or educational success. At country level, the map compares 'equity in education' (OECD, 2018): the deeper the red of the country (e.g. Germany, France), the more influence social background has, which means less educational mobility in comparison to other countries and therefore less 'equity in education'; the richer the green (e.g. Russia, Canada), the less influence social background has, which means more educational mobility in comparison to other countries, and hence more 'equity in education'.

2.1 of the fine analysis: How is the data for this map acquired? This is related to Harley's concept of external power: What is the specific practice of data acquisition? Or, in discourseanalytical jargon: What is the system of possibility for this kind of knowledge? What are the rules that permit such statements? (see Philp, 2000, p. 69). The data for this survey on 'equity in education' comes from so-called context questionnaires. In order to gather contextual information for the knowledge and skills in the main domains being analysed (reading, mathematics and science), PISA uses five additional questionnaires, including the 'Educational career questionnaire' and the 'Parent questionnaire' (OECD, 2018, p. 17). For example, the 'Parent questionnaire' includes questions for parents, such as: 'In the last twelve months, approximately how much have you paid to educational providers for services?' or 'What is your annual household income?' (OECD, 2017). In summary, one can say that statements about 'equity in education' are based on correlations between socio-economic factors and 'educational success' ('educational success' as defined by PISA).

2.2 of the fine analysis: How is this map used? This is related to Harley's concept of internal power: What is the discursive effect of the map? What are potential practices fostered by these discursive effects? While this would need further examination, first insights show that, for example, German-language newspapers which used this map (or variations of it) compared the results of the PISA survey for Germany with those of other countries (see e.g. Pauli, 2016; Schmidt, 2016). One factor for this cross-country comparison could be the national scale of the map - in Germany, the Federal state level plays an important role in regulations in education, and so discussion of this topic at a national level is not obvious. Articles using this map discuss other countries' education systems, which are assessed as being superior in terms of 'equity in education', and derived political demands based on this comparison, such as more resources for pupils with disadvantages based on starting conditions (Schmidt, 2016).

3. Summary of the first phase: How can the discourse strands which influenced the production of the map, as well as those that are influenced by the map produced, be described? What are their implicit norms? What is the most prominent one? What is the practice corresponding to the identified norm? Obviously, one prominent discourse strand concerns 'equity in education'. Its implicit ideal or norm could be called the effort principle, and its conflicting

\footnotetext{
${ }^{7}$ For legal reasons, we cannot provide the map here. Please follow the link: Map of PISA survey: Equity in education (http://www.compareyourcountry.org/pisa/?lg=en).
} 
practice the performance principle. While the performance principle demands, for example, the same remuneration for the same achievements/performances, the effort principle takes into account that individual achievements are also the results of social constellations (e.g. socio-economic background), and therefore some individuals need to spend more effort to achieve the same performance. This should reveal the core of the potential critique of the PISA survey: if an educational system pays less respect to starting conditions, it is closer to the practice of the performance principle and further away from the ideal of 'equity in education' with its implicit norm of the effort principle, which takes into account that some individuals need to spend more effort to achieve the same performance. Basing its view on the effort principle, the newspaper $T A Z$ interprets the PISA map as showing that 'Germany remains unfair' (Pauli, 2016), because there is less effective compensation for different starting conditions based on social inequality. By contrast, the performance principle would demand the same appreciation for the same achievements.

4. Examining the relationship between norm and its conflicting practice: So, what can an immanent critique based on the already quite radical norm, the effort principle, offer? In a first step, it would follow this norm of the PISA survey, but in a different way from internal critique: the reaction of internal critique is to demand compensation (as in the example of the newspaper article which demands more resources for pupils with 'deficits' (Schmidt, 2016)). While internal critique tries to dissolve this difference between norm (effort principle) and practice (performance principle) with different types of compensation, immanent critique paradoxically asks for a relationship between norm and its conflicting practice (see step 4). While this step does not work for every constellation and needs prior analysis and contextknowledge (Jaeggi, 2013, p. 298), it can lead to a completely new perspective, as we will now explain.

The PISA survey opens the perspective that the performance principle, which does not consider biographical inequalities when measuring individual performance, is 'unfair' (Pauli, 2016). But the PISA survey, on the other hand, uses the performance principle prominently in the assessments of the main domains (reading, mathematics and science). This leads to a tension, which should reveal the relationship between the norm (effort principle) and its conflicting practice (performance principle). The PISA survey does not really question the performance principle; it more or less invites us to look for ways to fix the performance principle, in the sense of: How can we compensate for the effect of biographical inequalities while preserving the performance principle?

This becomes clearer if we take a closer look at the map's colour scheme. The colour scheme invites us to compare different practices from different educational systems, which can be easily identified as better or worse. But even the nations with the richest green (e.g. Russia, Canada) use the the performance principle (for Canada, see e.g Mitchell, 2018). We can already find an echo of this framing in the subtitle of a newspaper article: 'PISA shows that socially disadvantaged students tend to do worse in science. But that need not be the case. Individual countries perform well despite major social differences' (Schmidt, 2016; own translation). The problem seems to be revealed now: it appears that the PISA survey offers a critique of 'unfair' conditions - e.g. different starting conditions due to socio-economic inequality. But quite the opposite is the case: the norm (effort principle) is even constitutive for the criticized practice (performance principle), in the sense that it invites us to search for ways to fix the performance principle (e.g. 
through compensation) (see steps $4 \mathrm{~b}$ and $4 \mathrm{c}$ in Section 4.1 above). It is not about 'fairness' anymore; it is not about abolishing social inequality; it is about performance: 'Individual countries perform well despite (!) major social differences' (ibid; own emphasis).

The immanent contradiction between the norm (effort principle) and its conflicting practice (performance principle) can be identified now as follows: based on the PISA survey, the performance principle needs to be criticized in contrast to the effort principle, because of the 'unfair' influence of socio-economic factors on performance-based 'educational success'. If we could compensate for socio-economic inaqualities (and not even countries like Canada, which are rated among the 'fairest' in the PISA survey, have achieved this yet (see Mitchell, 2018)), this would fix the problems of the performance principle and could lead to the called-for 'equity in education' despite the performance principle. This is what Jackson et al. (2005, p. 27) describe as 'the liberal dream of an education-based meritocracy' - a society whose allocation of privileges is based on 'merits'/performance under 'fair' conditions. The point here: based on 'fair' conditions (e.g. same starting conditions), hierarchies and social inaqualities would become justifiable. ${ }^{8}$ This is exactly where the immanent contradiction shows itself: while in the liberal perspective, social inequalities would be justifiable based on 'merits' under 'fair' conditions, these 'fair' conditions can only be created under the condition of social equality. So, the paradoxical point here is that an educational system/a society that is based on 'merits' or performance creates and justifies social inequality, but to create justifiable social inequality it needs social equality - at least as a starting point - as a prerequisite for 'fair' condititons. The practice fostered by this framework of an 'education-based meritocracy' is one of permanent compensation for social inequality (an inequality that is legitimated through this compensation), because it (should) create 'fair' conditions for the performance principle that produces and justifies social inequaltity.

Step 5 further discussion: Immanent critique 'surpasses the corrective critique by revealing the systemic difficulties of fulfilling the demands' (Herzog, 2016, p. 284). This example revealed the permanent, self-perpetuating, compensation for social inequality. Compensation in this context fixes and legitimates the performance principle, which produces and justifies social inequality (social inequality-based starting conditions are in the liberal perspective justifiable), which in turn requires new compensation. So, immanent critique does not argue morally that, for example, social inequality is wrong; it reveals the systemic difficulties of fulfilling the demands of 'fair' social inequality - it reveals dysfunctional aspects of an education-based meritocracy with its central idea of 'fair' social inequalitity. In this sense it is a mode of negative critique (see Flügel-Martinsen, 2016) - in contrast to constructive critique, it does not describe better alternatives - but it still has transformative potential, because it identifies the obstacle and its dysfunctional effect, and so offers a new perspective and raises new questions. In our example, it raises questions about performance measurement: while education should help to develop individuals' potentials, an 'education-based meritocracy' also requires some form of selection. While one could argue that a test, as an instrument of the performance principle, can

\footnotetext{
8 The ideal of an 'education-based meritocracy' consists of the triad 'education, career and income'. If the conditions in education are 'fair', a differentiation in 'educational success' would be justifiable and based on different educational qualifications, different career paths and different income. Finally, this triad of 'education-based meritocracy' justifies social inequality (see R. Becker \& Hadjar, 2009, p. 41; Kreckel, 2004). For further critique, see Goldthorpe (1996) and Solga (2013).
} 
serve as helpful feedback for students, in an 'education-based meritocracy' it is also an instrument for selection in the context of the meritocratic triad of education, career and income. This fosters what Goldthope (1996, p. 255) calls 'demonstrated competences', which refers to the need for educational qualifications in the context of an 'education-based meritocracy'. It is not so much about education or competences as such anymore, because the certification of an educational process and its measurement gain in importance. This shift in education leads Hauser to the conclusion that a central critique of meritocracy needs to focus on what he descibes as 'testocracy' (Hauser, 2002, p. 54). This leads to questions such as: What are the social effects of the current testing practice? 'There is more controversy than evidence about the effects of these tests [high school exit exams]. A reasonable speculation is that these exams will encourage early school dropout, especially among African-American and Hispanic youth, and that they will create new barriers to post-secondary education and training and to labor market entry' (ibid, p. 55). Based on the immanent contradiction, a critical examination of social effects of the current testing practice and other instruments for selection could be helpful to reduce the effect of the performance principle that produces and justifies social inequaltity.

\section{Conclusion and outlook}

Learning environments that are based on a practice such as reflexive map-reading offer the potential to go beyond an affirmation of given conditions, because they lead to points where these current conditions are conflictive or even dysfunctional. In contrast, learning environments that are in agreement with current social practices end in an affirmation of given conditions. Hence such learning environments foster not only integration into these conditions, but also (and mainly) adaptation to them, which can lead to effects of alienation (see Lehner \& Gryl, 2019b, pp. 14-15). On the other hand, learning environments that are based on immanent critique lead to social conditions that are conflictive, unfinished and open to change. Such learning environments do not foster adaptation to given conditions; they offer the potential to foster the sense of 'maturity' ('Mündigkeit') (Adorno \& Becker, 1971) and are aimed at the 'political subject' (Mitchell, 2018; Mitchell \& Elwood, 2013).

Certain questions remain. While this practice of reflexive map-reading based on immanent critique and discourse analysis seems to be promising for maps that cover topics around social practices (e.g. economics, ethnicity, crime, education, etc.), it does not seem to offer much potential for topographical maps (although their design and margins might still be questioned in deconstruction mode). We need also to further examine the method's practicability through practical applications in empirical settings, in order to identify potential problems and challenges. Furthermore, additional intermediate steps could be developed for the suggested two phases of the practice, which might increase its accessibility for a heterogeneous target group. 


\section{References}

Adorno, T. W., \& Becker, H. (1971). Erziehung zur Mündigkeit Vorträge und Gespräche mit Hellmut Becker 1959-1969 (25.). Suhrkamp.

Albert, H. (2010). Traktat über kritische Vernunft (Nachdr. d. 5., verb. und erw. Aufl). Mohr Siebeck. Becker, G. S. (1993). Der ökonomische Ansatz zur Erklärung menschlichen Verhaltens (2. Aufl). Mohr. Becker, L., Candeias, M., Niggemann, J., \& Steckner, A. (Eds.). (2017). Gramsci lesen: Einstiege in die 'Gefängnishefte' (Deutsche Originalausgabe, vierte Auflage). Argument.

Becker, R., \& Hadjar, A. (2009). Meritokratie - Zur gesellschaftlichen Legitimation ungleicher Bildungs, Erwerbs- und Einkommenschancen in modernen Gesellschaften. In R. Becker (Ed.), Lehrbuch der Bildungssoziologie (pp. 35-59). VS Verlag für Sozialwissenschaften. https://doi.org/10.1007/978-3-531-91711-5_2

Belina, B. (2009). Kriminalitätskartierung-Produkt und Mittel neoliberalen Regierens, oder: Wenn falsche Abstraktionen durch die Macht der Karte praktisch wahr gemacht werden. Geographische Zeitschrift, 97(4), 192-212. JSTOR.

Belina, B. (2010). Kriminalitätskarten - Sinnvolle Visualisierung eines sozialen Problems oder Ideologieproduktion? GW-Unterricht, 118, 5-19.

Belina, B. (2011). Kriminalitätskarten in den Medien. In H. Peters \& M. Dellwing (Eds.), Langweiliges Verbrechen (pp. 115-130). VS Verlag für Sozialwissenschaften. https://doi.org/10.1007/978-3531-93402-0_7

Belina, B. (2013). Raum (1. Auflage). Westfälisches Dampfboot.

Boltanski, L., \& Chiapello, È. (2006). Der neue Geist des Kapitalismus (Broschierte Ausgabe). UVK Verlagsgesellschaft.

Butler, J. (2016). Was ist Kritik? Ein Essay über Foucaults Tugend. In R. Jaeggi \& T. Wesche (Eds.), Was ist Kritik? (pp. 221-246). Suhrkamp.

Candeias, M. (2008). Von der Dialektik des Neoliberalismus zu den Widersprüchen der Bewegungen. In C. Butterwegge, B. Lösch, \& R. Ptak (Eds.), Neoliberalismus: Analysen und Alternativen (pp. 301-317). VS Verlag für Sozialwissenschaften.

Crampton, J. W., \& Krygier, J. (2010). An Introduction to Critical Cartography. ACME: An International E-Journal for Critical Geographies, 4, 11-33.

Demirović, A. (Ed.). (2008). Kritik und Materialität (1. Aufl). Verl. Westfälisches Dampfboot.

Flügel-Martinsen, O. (2016). Negative Kritik. In U. Bittlingmayer, A. Demirovic, \& T. Freytag (Eds.), Handbuch Kritische Theorie (pp. 1-16). Springer Fachmedien Wiesbaden. https://doi.org/10.1007/978-3-658-12707-7_31-1

Foucault, M. (1988). Madness and civilization: A history of insanity in the age of reason (Vintage Books Ed., Nov. 1988). Random House.

Foucault, M. (1995). Discipline and punish: The birth of the prison (2nd Vintage Books ed). Vintage Books.

Foucault, M. (2007). The politics of truth. Semiotext(e).

Foucault, M. (2017a). Der Wille zum Wissen. Suhrkamp.

Foucault, M. (2017b). Die Ordnung der Dinge: Eine Archäologie der Humanwissenschaften (24th ed.). Suhrkamp.

Glasze, G. (2009). Kritische Kartographie. Geographische Zeitschrift, 181-191. https://doi.org/10.2307/23031916

Goldthorpe, J. H. (1996). Problems of „Meritocracy“. In R. Erikson \& J. O. Jonsson (Eds.), Can education be equalized? The Swedish case in comparative perspective (pp. 255-287). Westview Press.

Gryl, I., \& Jekel, T. (2012). Re-centring Geoinformation in Secondary Education: Toward a Spatial Citizenship Approach. Cartographica: The International Journal for Geographic Information and Geovisualization, 47, 18-28. https://doi.org/10.3138/carto.47.1.18 
Gryl, I., \& Kanwischer, D. (2011). Geomedien und Kompetenzentwicklung-Ein Modell zur reflexiven Kartenarbeit im Unterricht. Zeitschrift Für Didaktik Der Naturwissenschaften, 17, 203-222.

Harley. (1989). Deconstructing the Map. Cartographica, 26, 1-20. https://doi.org/10.3138/e635-7827$1757-9 \mathrm{t} 53$

Harley, J. B. (1988). Silences and Secrecy: The Hidden Agenda of Cartography in Early Modern Europe. Imago Mundi, 40, 57-76. JSTOR.

Harley, John B. (1988). Maps, knowledge, power. In D. E. Cosgrove \& S. Daniels (Eds.), The iconography of landscape: Essays on the symbolic representation, design and use of past environments. Cambridge Univ. Press.

Hauser, R. M. (2002). Meritocracy, Cognitive Ability, and the Sources of Occupational Success. CDE Working Paper No. 98-07, Center for Demography and Ecology. University of Wisconsin- Madison.

Herzog, B. (2013). Ausschluss im (?) Diskurs. Diskursive Exklusion und die neuere soziologische Diskursforschung. Forum Qualitative Sozialforschung / Forum: Qualitative Social Research, Vol 14, No 2 (2013). https:/ /doi.org/10.17169/FQS-14.2.1910

Herzog, B. (2016). Discourse analysis as immanent critique: Possibilities and limits of normative critique in empirical discourse studies. Discourse \& Society, 27(3), 278-292. https://doi.org/10.1177/0957926516630897

Institut für Staatspolitik. (2004). Kritik als Ideologie. Die „Kritische Diskursanalyse“ des Duisburger Instituts für Sprach- und Sozialforschung.

Jackson, M., Goldthorpe, J. H., \& Mills, C. (2005). Education, Employers and Class Mobility. Research in Social Stratification and Mobility, 23, 3-33. https://doi.org/10.1016/S0276-5624(05)23001-9

Jaeggi, R. (2009). Rethinking Ideology. In B. de Bruin \& C. F. Zurn (Eds.), New Waves in Political Philosophy (pp. 63-86). Palgrave Macmillan UK. https://doi.org/10.1057/9780230234994_4

Jaeggi, R. (2013). Kritik von Lebensformen. Suhrkamp. http://nbn-resolving.de/urn:nbn:de:101:12014021215002

Jekel, T., Gryl, I., \& Oberrauch, A. (2015). Education for Spatial Citizenship: Versuch einer Einordnung. GW-Unterricht, 137, 5-13.

Kreckel, R. (2004). Politische Soziologie der sozialen Ungleichheit. Campus.

Lehner, M., \& Gryl, I. (2019a). „Neoliberalismus“. Diskussion eines Grundbegriffs zur Analyse sozioökonomischer Gegenwart und zur Reflexion von Bildungsinhalten. GW-Unterricht, 1, 5-16. https://doi.org/10.1553/gw-unterricht155s5

Lehner, M., \& Gryl, I. (2019b). Neoliberalismus in NRWs Sachunterrichtsbüchern? GW-Unterricht, 4, 5-18. https://doi.org/10.1553/gw-unterricht156s5

Lehner, M., Pokraka, J., Gryl, I., \& Stuppacher, K. (2018). Re-Reading Spatial Citizenship and ReThinking Harley's Deconstructing the Map. GI_Forum, 1, 143-155.

https://doi.org/10.1553/giscience2018_02_s143

Leser, H., \& Broll, G. (Eds.). (2005). Diercke Wörterbuch Geographie. Westermann.

Leser, H., \& Broll, G. (Eds.). (2017). Diercke Wörterbuch Geographie (16., völlig überarbeitete Auflage, Druck A). Westermann.

Marx, K. (1981). Capital: A critique of political economy. Penguin Books.

Mitchell, K. (2018). Making workers: Radical geographies of education. Pluto Press.

Mitchell, K., \& Elwood, S. (2013). Intergenerational Mapping and the Cultural Politics of Memory. Space and Polity, 17, 33-52. https://doi.org/10.1080/13562576.2013.780712

OECD. (2017). Parent questionnaire. http://www.oecd.org/pisa/data/2018database/CY7_201710_QST_MS_PAQ_NoNotes_final.pdf

OECD. (2018). Equity in Education: Breaking Down Barriers to Social Mobility. OECD. https://doi.org/10.1787/9789264073234-en

Pauli, R. (2016). Ernüchternde Pisa-Studie. Deutschland bleibt unfair [Https://taz.de/ErnuechterndePisa-Studie/!5360069/]. 
Philp, M. (2000). Michel Foucault. In Q. Skinner (Ed.), The return of grand theory in the human sciences (Reprint, pp. 65-83). Cambridge Univ. Press.

Pinder, D. (2003). Mapping worlds. In A. Blunt, P. Gruffudd, J. May, M. Ogborn, \& D. Pinder (Eds.), Cartography and the politics of representation (pp. 172-187). Hodder Arnold.

Romero, J. M. (Ed.). (2014). Immanente Kritik heute: Grundlagen und Aktualität eines sozialphilosophischen Begriffs. Transcript.

Saar, M. (2007). Genealogie als Kritik: Geschichte und Theorie des Subjekts nach Nietzsche und Foucault. Campus Verlag.

Saar, M. (2016). Genealogische Kritik. In R. Jaeggi \& T. Wesche (Eds.), Was ist Kritik? (pp. 247-265). Suhrkamp.

Schmidt, F. (2016). Sozial Schwache und Arme müssen nicht Verlierer im Bildungssystem sein. https://www.dw.com/de/sozial-schwache-und-arme-müssen-nicht-verlierer-im-bildungssystemsein/a-36660400

Schuurman, N. (2000). Trouble in the heartland: GIS and its critics in the 1990s. Progress in Human Geography, 24(4), 569-590. https://doi.org/10.1191/030913200100189111

Solga, H. (2013). Meritokratie - die moderne Legitimation ungleicher Bildungschancen. In P. A. Berger \& H. Kahlert (Eds.), Institutionalisierte Ungleichheiten: Wie das Bildungswesen Chancen blockiert (pp. 19-39). Beltz-Juventa.

Spivak, G. C. (2007). Can the Subaltern Speak?: Postkolonialität und subalterne Artikulation (A. Joskowicz \& S. Nowotny, Trans.). Turia + Kant.

Stahl, T. (2013). Habermas and the Project of Immanent Critique. Constellations, 20(4), 533-552. https://doi.org/10.1111/1467-8675.12057

van Dijk, T. (2009). Critical Discourse Studies: A Sociocognitive Approach. In R. Wodak \& M. Meyer (Eds.), Methods of Critical Discourse Analysis (pp. 62-85). SAGE.

Varela, M. do M. C., \& Dhawan, N. (2015). Postkoloniale Theorie: Eine kritische Einführung. transcript. Vighi, F., \& Feldner, H. (2007). Ideology Critique or Discourse Analysis?: Žižek against Foucault. European Journal of Political Theory, 6(2), 141-159. https://doi.org/10.1177/1474885107074347

Žižek, S. (2012). Less than nothing: Hegel and the shadow of dialectical materialism. Verso. 